\title{
Iraqi Invasion of Kuwait as Turning Point in Iran-Saudi Relationship
}

\author{
Reza Ekhtiari Amiri \\ Politics and Government \\ Department of Government and Civilization Studies \\ Faculty of Human Ecology, Universiti Putra Malaysia (UPM) \\ 43400 Serdang, Selangor, Malaysia \\ Tel: 60-17-620-7617 E-mail: ekhtiari2002@gmail.com or ekhtiari_reza@yahoo.com
}

\author{
Fakhreddin Soltani \\ Politics and Government \\ Department of Government and Civilization Studies \\ Faculty of Human Ecology, Universiti Putra Malaysia (UPM) \\ 43400 Serdang, Selangor, Malaysia \\ Tel: 60-17-326-4325Ｅ-mail: Fakhreddinsoltani@yahoo.com
}

\begin{abstract}
Invasion of Kuwait by Iraqi army had significant impacts on regional and international spheres. The invasion affected relations of the regional countries in particular Iran-Saudi relationship as the most influential countries in the Persian Gulf region. The present article, first, takes into consideration Iran and Saudi Arabia relations in first decade after the Islamic revolution of Iran which finally gave rise to cutting off diplomatic relations in 1988 due to some severe tensions between the two sides. Then, the article examines Iraq's invasion of Kuwait and occupying of Kuwait city, the capital, in August 1990 which led to some significant regional developments. The study also analyzes Iran's neutrality stance in this case as well as in Second Gulf War which was reaction of international community pertaining to the occupation. Finally, the article concludes that how Iranian rational and pragmatic decision during the crisis resulted in changing of viewpoints of regional countries in particular Saudi Arabia which eventually led to renewing of diplomatic ties of Tehran-Riyadh in March 1991 after three years frigidity.
\end{abstract}

Keywords: Iran, Saudi Arabia, Kuwait, Neutrality, Second Gulf War, Persian Gulf Region

\section{Iran -Saudi Relations in First Decade after Islamic Revolution of Iran}

Overthrowing of Pahlavi regime in 1979 and emergence of Iran's Islamic revolution caused serious problems for neighboring countries such as Saudi Arabia, Kuwait, and Bahrain due to encompassing some Shiites minorities within their territories. Amongst them, Saudi Arabia had faced the most vexing questions such as riots in eastern province of Al-Sharghiya in November 1979 and February 1980, as well as insurgency of Salafi radical groups and occupation of the Masjid Al-Haram (Grand Mosque) in Mecca. The Kingdom faced more challenges later due to endeavors of the new Iranian regime for spreading revolutionary thoughts as well as organizing political demonstration so-called "liberation from infidels" in Mecca by Iranian pilgrims against United States and Israel. It was at the time when Ayatollah Khomeini argued that “...the Islamic world must turn to Iran's leadership to win its freedom and independence" (Parsi 2007). In total, Iran's new regime, under radical ideological atmosphere, had adopted the "bellicose foreign policy" which threatened the Gulf states' legitimacy in particular those which enclosed Shiite community.

Therefore, Saudi rulers made themselves ready to encounter Islamic republic of Iran and especially its exporting of the revolution. They reformed and changed several internal and regional policies in order to preserve their stability. For instance, they arrested or deported potential dissidents, provided greater economic benefits to their own Shiite populations, trumpeted their own Islamic credentials, and emphasized on Arab nationalism rather than Islamic unity (Walt, 1996). By starting of Iran-Iraq war in 1980, furthermore, they formed Gulf Cooperation Council (GCC) in January 1981 in order to coordinate their activities against Iranian threat. Saudi Kingdom also assisted Iraq politically, economically during Iraq-Iran war in 1980s in order to stop Iran's new policies. Regarding Saudi support of Iraqi government and deterioration of Iran and Saudi Arabia ties, Husseini (2007) states that Saudi Arabia loaned 30 billion dollars to Iraq, and also Iraq was allowed to use Saudi Arabia airports and ports for military shipments .On the top of all, Saudi Arabia was selling 280,000 barrel oil daily in favor of Iraqi government from neutral region. Indeed, in this period the preceding cordial relations of the two countries had become frigidity due to 
Iranian revolutionary thoughts and activities in the region which threatened legitimacy of littoral states such as Saudi Arabia that involved Shiite population.

By increasing international pressure; Iran initiated a brief détente with Saudi Arabia in mid-1980s in an attempt to persuade the Saudis to reduce their support of Iraq. Hashemi Rafsanjani (then parliament speaker) assured Riyadh that Iran had no intention of controlling Ka'ba and Mecca which was responded by inviting Rafsanjani to visit Mecca during the Hajj ritual (Walt, 1996). However, the invitation was turned down by Ayatollah Khomeini. Meanwhile, oil price turned to become a challenging issue between the two countries. In one hand, reduction of world demand for oil as well as emergence of new oil producers such as Norway, United Kingdom, and United States led to falling of oil price in the world and as a result share of the Organization of Petroleum Exporting Countries (OPEC) declined from 50 to 29 percent (Robert, 2005). On the one hand, by increasing of production Saudi Arabia declined oil price intentionally with the purpose of reduction of Iran's oil incomes as major resource of the war expenditures (Yaqubi, 2009).

In this juncture, due to Iran's economic and political isolations, Saudi Arabia became the most influential actor amongst Muslim in particular Arab countries in light of its donation which was stemmed from oil wealth (Abir, 1993). Riyadh, likwise, strengthened its regional role during Iran-Iraq war which caused Tehran's annoyance and as a result termed Saudi action as "unilateral Saudi decision" in favor of the West (Al-Suwaidi, 1996). Later, in 1986, clashes between Iranian pilgrims and Saudi security forces during the hajj led Rafsanjani to proclaim that Iran must "uproot the Saudi rulers... and divest the control of the shrines from [them]" (Walt, 1996, p.245) while the clashes were due to Iran's endeavors to export its revolution during the hajj and also political demonstration of Iranian pilgrims which threatened Saudi legitimacy and stability. This is why; the annual hajj was the main problem between the two sides not Saudi support of Baghdad during Iran-Iraq war in 1980s (Metz, 2004).

In other words, politicizing the hajj seemed to be the main tension between the two sides which had continued up to 1987. In this year, clashes between Iranian-led demonstrators and Saudi security forces left a tragedy outbreak on 31 July 1987. The event which left 275 dead and 303 wounded of Iranian pilgrims, was the worst tension since the Islamic revolution in 1979. It caused much argumentation and propaganda between the two sides. In this regard, Imam Khomeini vowed that "Even if it were possible to forgive Saddam Hussein, it would never be possible to forgive Saudi Arabia"(Ismael \& Ismael, 1994, p. 194). Imam Khomeini also said that Fahd (Saudi King, 1982-2005) "will not remain alive". Hashemi Rafsanjani, likewise, announced that: "The martyrs' blood must be avenged by burning the roots of Saudi rulers in the region. ...The true revenge is to remove the colossal and precious wealth belonging to the Islamic World which lies under the soil of the Arabian Peninsula from the control of criminal, the agents of colonialism. The Saudi rulers have chosen an evil path, and we will send them to hell" (Mohaddessin, 2003, pp. 94-95).

When the news of the riot and the casualties reached Iran, mobs attacked the Kuwaiti and Saudi embassies, Iraq's allies in the war, (Institution for Political Research and Studies, 2007) which led to death of a Saudi diplomat, Mousa'ad Al Ghamdi. According to Gulfnews (2007) " [He] died in Tehran of wounds sustained when he fell out of an embassy window and Riyadh accused Tehran of delaying his transfer to a hospital in Saudi Arabia." The events along with argumentation on new Saudi's hajj quota, led to cutting off mutual relations of the two sides in April 1988. Based on the new quota, 1000 pilgrims per million for each country, Iran could only send 45,000 pilgrims to hajj ceremony while Iran's quota was approximately 150,000 before the incidence. In addition, Iran insisted to hold the political demonstration like previous years while Saudi Arabia was afraid of Iranian pilgrims. In general, as it is evident, Iran's revolutionary policy or so-called "anti-quo policy" under Iran-Iraq war atmosphere gave rise to intensive response of Saudi Kingdom. In fact, they were afraid that Iran's attempt for exporting of revolution would endanger Saudi regime and authority. That is why; it was observed that Saudi Arabia attempted to apply any tools especially during Iran-Iraq war to encounter Iran. This period, 1980s, was indeed the most tensional term in mutual relations of the two countries since establishment of formal diplomatic relations in 1929.

\section{Iraqi invasion of Kuwait}

From a historical viewpoint, Iraq and Kuwait were parts of Basra province in the time of Ottoman Empire. However, Iraq accounted Kuwait as part of its soil. " [The] allegation was based on the administrative system of the Ottoman Empire ...” (Dijk, 2008, p. 458). That is why, after independence of Kuwait in 1961, Iraq invaded Kuwait with pretext of ownership of the country which finally was repelled by the British army (Mansbach \& Rafferty, 2008).

However, occupation of Kuwait in 1990 was in the light of different excuses. The main motive for invasion was "economic character". In fact, economic pressure remained from Iran-Iraq war, refusal of Iraq's supporters (in particular Saudi Arabia and Kuwait) to forgive Iraq's debts, about $\$ 50$ billion, as well as Baghdad's accusation of Kuwait for extracting Iraqi oil (Dijk, 2008) along with low price of oil in late 1980s, between $\$ 13$ and $\$ 19$, provided 
difficult situation for Iraq which finally persuaded Saddam Hussein to capture Kuwait's oil supplies. In addition to economic factor, Iraq's intention for restoring its lost regional power after the eight-year war formed another reason. Saddam, Iraqi leader, who constantly had ambition of being regional power, indeed, by occupation of Kuwait could "control 20 percent of OPEC production and 25 percent of world oil reserves... which helped him to be the dominant power in the Persian Gulf, and also well equipped to resume his war with Iran" (Schaeffer, 2005, p. 266). In this case, Kuwait's wealth in one hand and its military weakness on the other hand persuaded Iraq to dominate its hegemony in the region after Iran-Iraq war.

Despite of the facts, "ingratitude" of Kuwaiti government, while Iraq had represented all Arabs in Iraq-Iran war, (Mansbach \& Rafferty, 2008) along with psychological aspect remained from the war, failure of Saddam Hussein to win Iran-Iraq war, were other excuses. In this regard, Kamrava (2005) argues that Saddam wanted to hand his general "...quick and easy victory that had eluded them for eight years in the war with Iran, and this time the rewards - the looting and plunder of one of the world's richest countries- were far more handsome and immediate" (p.184). By the occupation, in fact, Saddam ,to some extent, wanted to revive Iraq's prestige as the most powerful Arab country in the region. Although economic and political situation of Iraq were not in appropriate level after the first Gulf war (Iran-Iraq war), however, its military force was still powerful (Gettleman \& Schaar, 2003). Finally, on August 2, 1990 Saddam sent his army, 150,000 troops and 2000 tanks, into Kuwait and occupied it in less than a week on August $6^{\text {th, }}$ and formally annexed Kuwait as Iraq's nineteenth province.

\section{Second Gulf War as United Nations Reaction}

After the invasion, United Nations (UN) declared for Iraq's withdrawal of Kuwait "immediately and unconditionally", and also announced that it will use all "necessary means", including military force, in the framework of the final provision -Article 51- of Chapter VII of the Charter. The Article affirms "the inherent right of individual or collective self-defense if an armed attack occurs against a Member of the United Nations, until the Security Council has taken measures necessary to maintain international peace and security" (Scheffer, 1991, p. 109). Despite of the announcement, Saddam changed the name of Kuwait as "Kadima", the name from the Ottoman era (Dijk, 2008).

Iraqi invasion had faced with response of international community. In this regard, Margaret Thatcher, then British Prime Minister, said that "Iraqi invasion of Kuwait defies every principle for which the United Nations stands. If we let it succeed, no small country can ever fell safe again. The law of the jungle would take over from the rule of law. ... Iraq, declared Bush (then president of United States), will not be permitted to annex Kuwait. And that's not a threat. It's not a boast. It's just the way it is going to be" (Mansbach \& Rafferty 2008, p.237). Indeed, at the time being, it can be seen that a global consensus had been formed against Iraq which headed by United States as the only superpower after collapse of former Soviet Union. In other words, this stage is regarded as first practical action of United States for proving of formulation of unipolar world.

As practical response, first, United States froze the Iraq's and Kuwait's assets and blocked oil imports from Iraq which followed by other allies such as United Kingdom, Japan, and France. Soviet Union, as Iraq's previous ally, also stopped arms deliveries to Iraq (Dijk 2008). Then, with UN approval the United States sent 400,000 troops on January 17 1991, and American and British warplanes started bombing Iraq's military targets. The land operation which was began on February 23, ended in 100 hours by Iraq's defeat on February 27 (Dijk 2008). In this case, although the coalition against Iraq included thirty-six countries, however its main contributors were the United States, Great Britain and Saudi Arabia (Kamrava, 2005) while Saudi Arabia was one of the major supporters of Iraq in Iran-Iraq war. Eventually, in February 1991, after nineteen UN resolutions, Saddam Hussein accepted to withdraw from Kuwait and the cease-fire agreement with Iraq was codified in United Nation Security Council Resolution (UNSCR) 687 in April of 1991. Based on the resolution, "Iraq was required to recognize its border with Kuwait and provide compensation for losses from the occupation” (Thies, 2006, p. 195).

The operation of liberation of Kuwait which is known as "Desert Storm", however, did not give rise to collapse of Saddam's regime. Therefore, after the elimination of the Second Gulf War, when Saddam survived from a battle that he called it "mother of all battles" (Mansbach \& Rafferty 2008), he began to squash Shiite and Kurd's rebellion cruelly. While the uprising was “at least in part because of the Bush administration's call for the people of Iraq to depose their leader" (Thies, 2006, p.195), however, Bush's administration eventually decided not to back the groups because they feared that the consequence would strengthen Iran's power in the region. Finally, UN determined "no-fly zones" in order to protect Kurds in north and Shiites in south of Iraq which was carried out by United States and British Aircrafts. At the same time, invasion of Iraq to Kuwait and subsequently Iran's appropriate foreign policy towards the crisis led to improvement of Iran's position in the region as well as world. 


\section{Iran's Neutrality in the Crisis and Relation with the Persian Gulf Countries}

During the Kuwait crisis, Tehran attempted to make appropriate decision in order to direct the crisis in favor of itself. It was at the time when Iran was struggling with socio-economic problems inside of the country and economic re-construction was in the core of the Iran's foreign policy. That is why, when Saddam Hussein had strived to persuade Iran to enter the war, its proposal was overlooked by Iranian leaders. In this case Washington post issued that despite of "peace offer" by Saddam Hussein, which had not been signed between Iran and Iraq after the eight-year war, Hashemi Rafsanjani stressed on demand for Iraq's withdrawal from Kuwait (Hufbauer, Schott, \& Elliott, 1991). In fact, Hashemi Rafsanjani's administration had chosen 'active Neutrality' in order to "maximize Iran's national interests by standing on the sidelines without antagonizing either Baghdad or Washington" (Al-Suwaidi, 1996, p. 92). In this case, Velayati, then Iranian foreign minister, declared that Iran will not enter in favor of any part in the war, and will not permit them to use Iran's soil or sea and air space (Marschall, 2003).

When the Second Gulf war took place, Iran faced with internal opponents who supported Iran's intervention in the Second Gulf War in favor of Iraq. They said that "The great leader [Ayatollah Khomeini] described confrontation with American in the Persian Gulf as jihad for the sake of God and being slain as martyrdom for the Sake of God" (Daneshkhu, 1994, p. 301). Nevertheless, Hashemi Rafsanjani rejected hardliners's offer, such as Mohtashami (then Interior Minister), to interfere in Iraq during the war because he was in favour of "moderation" (Ehteshami \& Hinnebusch, 1997). Hashemi, in addition, believed that participation in the war was "suicide" (Daneshkhu 1994). In this respect, also, the supreme leader Ayatollah Khamenei maintained Rafsanjani's position of neutrality. Therefore, Iran stayed away from the war which might cause some problems for it while Iran was attempting to solve the existing problems resulted from the eight-year war such as high inflation, unemployment, difficulties of health and education sections alongside regional and international isolation.

In total, Iraq's invasion to Kuwait “....provided Iran with the ideal opportunity to demonstrate to the West the danger of Saddam Hussein and to drive home the point to the Persian Gulf Arab states that they were wrong to have supported Iraq in the Iran-Iraq war"(Ismael \& Ismael, 1994, p. 296). Iran, further, used "Saddam's aggression to remind the international community that Iraq- and not Iran - was the real threat to regional peace and security" (Parsi, 2007, p. 142) and also Iran could prove that Iraq was the aggressive country in the eight-year war, as it was announced later by UN.

In addition, Iran's neutrality stance and its endeavor for solving the problem gave rise to releasing of Iran from international isolation. In other words, Iran's pragmatic decision in the crisis presented it as rational and responsible actor which changed Iran's image in the region and world and paved the way for international cooperation. Iran also could take back some part of its territory and also improved its relations with neighboring Arabian states and increased country's revenue which was resulted from rising of oil price in that period (Marschall, 2003). Moreover, Second Gulf War made Iraq weak as Iran's old enemy and provided the ground for Iranian leaders to streghthen their military cababilities as well as their influence in the region (Levran, 1997). However, in order to regain its previous role in the region, Iran needed to make progress in its relationship with United States and Persian Gulf states (Parsi, 2007). It was because of extensive presence of American forces in the region after the Gulf war and cordial relationship of the Arab countries with United States. Since restoring of Iran's relation with United States was very difficult and sophisticated due to their prior tensions and also Iran's inappropriate policies in the region and world; renewing ties with the Persian Gulf states became top priority of the Hashemi Administration. In this case, Hashemi declared that: "Iran's foreign policy is based on development and expansion of friendly relations with neighboring countries in particular Persian Gulf countries. ..." (Ettelaat Newspaper, 1992). In other words, Hashemi's approach in foreign policy relied on revival of relations with the littoral states in the south and also normalization of Iran's ties with world in order to improve national development. Hashemi said: "relations with neighbors, Islamic countries and Third World countries have top priorities in Iranian foreign policy" (Ettelaat Newspaper, 1996). Accordingly, Saudi Arabia as well as other Gulf countries was part of all three categories which Hashemi mentioned above.

In this regard, Al-Suwaidi (1996) states that Hashemi Rafsanjani pursued three objectives: firstly he intended to keep Iraq under control, secondly he attempted to improve Iran's ties with Persian Gulf states, and thirdly he wanted to increase Iran's influence on oil policy for lower production as well as higher price. Indeed, the objectives were resulted of internal economic crisis which the administration had faced with them. As a consequence, with regard to Iran's stance in the crisis and also its attempt for renewing relations with the Persian Gulf states, in December 1990 summit in Qatar, the GCC members "....welcomed the prospect of future cooperation and Iranian participation in regional security arrangement" (Nonneman, 2005, p. 180) and for the first time they regarded Iran as "acceptable partner" in security of the Persian Gulf (Ehteshami \& Hinnebusch, 1997). Further, in final declaration of GCC, leaders of six member countries asked for establishing of special relations with Iran "(Ettelaat Newspaper, 1990c) . In sum, the regional events, as Hiro (2001) terms it "unprecedented opportunities", and subsequently appropriate 
decision of Iran for not to interfere in the crisis gave rise to improvement of relations between Iran and the Persian Gulf countries by mediatory role of Syria.

\section{Iraq's Invasion of Kuwait: Restoring of Iran-Saudi Diplomatic Relations}

When Iraqi army invaded Kuwait, at first, Saudi Arabia was only cautious regarding the crisis and did not consider it as serious danger pertaining to its territorial integrity and sovereignty. But, "Information leaked in Baghdad that the Iraq's war machine might not stop at the border between the $19^{\text {th }}$ Iraq's provinces (Kuwait) and Saudi Arabia but might carry the war deep into the Saudi oil province of al-Hasa" (Kaim, 2008, p. 127). In other words, "Saudi Arabia became Saddam's next victim" (Abir, 1993). Indeed, with the purpose of expanding of regional dominance, once more, Iraq was about to occupy another rich country. Although Iraqi forces were placed along the Saudi border however the Kingdom did not take action practically due to its fear from leader of Iraq until noticeable American forces entered its land. Deploying of the forces in Saudi Arabia by virtue of Iraqi threat over its oil resources (Dijk 2008) was a deffensive effort which was named as "Operation Desert Shield" (Mansbach \& Rafferty, 2008). Briefly, Saudi Arabia, previous ally in First Gulf War, was placed in the core of Iraq's hostility.

Anyway, occupation of Kuwait along with Iraqi hostility on Saudi Arabia changed balance of power in favor of Iran in several ways. In this regard, "...Iraq replaced Iran as the immediate threat to security and integrity of [the Gulf countries]" (Nonneman, 2005, p. 180) and also the Gulf countries accepted Iran as "counter" to Iraq (Ehteshami \& Hinnebusch, 1997). At the same time, fear of Saudi Kingdom resulted in mutual negotiation between Tehran and Riyadh. In order to attract Iranian attention, Saudi officials reiterated that "The Kingdom did not stand against Iran at all [in Iran-Iraq war]. ...But we were in a position with no alternative. We had to stand by an Arab state [Iraq] defending itself and protecting us from evil. But circumstances change. ... King Fahd, moreover, claimed that Kuwaiti and Saudi Arabia financial assistance to Iraq had not been aimed at an invasion of Iran but at Iraq's defense. He said that he had personally tried to dissuade Saddam from invading Iran and referred to past events between Iran and Saudi Arabia as aberrations" (Ismael \& Ismael 1994, p.306). Saudi leadership, moreover, added that their support for Iraq was "without malice for Iran" (Wilson \& Graham, 1994). All speeches, indeed, indicated Saudi endeavor to justify its heavy support of Iraqi government during the eight-year war in order to attract Iran's attention for improvement of relations. To achieve the goal, Saudi Arabia even dissembled Iran's relations with the Shiites in south of Iraq, and after ending of occupation of Kuwait called for renewing of ties with Iran and also hajj became no longer as contradictory symbol of the two Islamic countries (Husseini, 2007).

In this case, Hashemi's stance toward Kuwait crisis had very important role in changing mind of Saudi Arabia and other Persian Gulf countries. Hashemi declared that "Iran does not accept geographical changes. Iran just intends to solve regional problems. So, regional countries should not be worry" (Ettelaat Newspaper, 1990a). In fact, Iran's stance indicated that Iran did not follow aggressive policy and in return it was a country which chased peace and stability in the region. Therefore, after declaring of Kuwait as Iraq's nineteen provinces, Iran's foreign ministry "condemned Iraqi annexing of Kuwait by issuing a declaration. In this condemnation it was stated that such action was violation of certain right of a nation to determine their destiny" (Ettelaat Newspaper, 1990b). Actually, Iranian positive position in favor of Kuwait introduced Iran as a rational and responsible country in the region which caused Persian Gulf states reduce their media and propaganda attack against Iran. Iran also understood if it wanted to resolve internal and regional problems such as economic reconstruction and regional political isolation it had to work with the regional countries especially with Saudi Arabia. Saudi Arabia, in one hand, was a key neighbor in the Persian Gulf region due to its influence on Arab neighboring countries and on the other hand it has had significant role in determination of the oil price in OPEC. Since oil revenues has been known as "backbone" of Iranian economy, so it seemed that Iran attempted to restore and develop its relations with Saudi Arabia.

As it is evident, regional development helped the two countries to become close to each other and reconcile their policy in the region. In fact, as Kaim (2008) argues, Iraqi invasion gave rise to détente between Iran and Saudi Arabia and Iranian leaders started following the slogan of "the enemy of my enemy is my friend" (p.127). The writer continues that détente between the two sides was "the most remarkable success" of Iranian foreign policy during the Kuwait crisis which led to full diplomatic relations between the two countries on 19 March 1991. In short, according to Metz (2004), some factors such as emergence of Iraq as a "mortal enemy", "Tehran's consistent demands" for withdrawal of Iraq from Kuwait as well as Iran's "neutrality" stance during the conflict led to weakening of hostile attitude toward Iran. Therefore, only months after the end of the Gulf crisis, Iran and Saudi Arabia normalized their relations.

\section{Conclusion}

As revealed earlier, despite of Iran-Saudi frictional relations in first decade of Iran's revolution because of some matters such as political demonstration in hajj ceremony or Saudi fear of ideological slogans like exporting the 
Islamic revolution which led to cutting off diplomatic relations between the two sides; Saddam's occupation of Kuwait and subsequently Second Gulf War which headed by United States, changed Iran-Saudi hostile perception from one another and paved the way for restoring of mutual diplomatic relations after three years in March 1991. Indeed, Iraq's invasion of Kuwait was a turning point in regional developments which changed the political and security atmosphere of the region in favor of Iran. Iran by following policy of neutrality, not only could leave international isolation and pressure resulted from its prior belligerent policy, but also improved its relations with southern neighbors in Persian Gulf in particular with Saudi Arabia as the most important actors in the region as well as in Muslim world. In other words, Iran's stance in the crisis alongside its cooperation with the international coalition and also fear of Saudi ruler from Iraq's danger had very significant impact on Saudi Kingdom in the direction of restoring mutual relations with Iran aimed at encountering risk of Iraq. Notwithstanding of the facts, moreover, Iran and Saudi Arabia realized that they could benefit more if they had collaborative behavior in the region; that is why, it was observed that the two sides attempted to resolve outstanding problems and improve their mutual relations in the following years.

\section{References}

Abir, M. (1993). Saudi Arabia: Government, Society, and the Gulf Crisis. London: Routledge.

Al-Suwaidi, J. S. (1996). Iran and the Gulf: A Search for Stability. London: I.B.Tauris.

Daneshkhu, S. (1994). Iran and the New World Order. In T. Y. I. Ismael, Jacqueline (Ed.), The Gulf War and the new world order (pp. 293-317). Gainesville: University Of Florida.

Dijk, R. V. (2008). Encyclopedia of the Cold War. London: Taylor\& Francis.

Ehteshami, A., \& Hinnebusch, R. A. (1997). Syria and Iran. London: Routledge.

Ettelaat Newspaper (1990a, 9 September). Hashemi in ceremony of week of Holy Defense. Ettelaat Newspaper, p. 3. Retrieved October 2009.

Ettelaat Newspaper (1990b, 11 August). Iran's foreign ministry refused Iraqi attachment of Kuwait. Ettelaat Newspaper, p. 3. Retrieved October 2009,

Ettelaat Newspaper (1990c, 26 September). Six Arab countries of the Gulf asked for especial relations with Iran. Ettelaat Newspaper, p. 12. Retrieved September 2009,

Ettelaat Newspaper (1992, 8 February). Ettelaat Newspaper, p. 19. Retrieved October 2009,

Ettelaat Newspaper (1996, 8 August). The President announced Iran's readiness for solving Africa problems Ettelaat Newspaper, p. 3. Retrieved October 2009,

Gettleman, M. E., \& Schaar, S. (2003). The Middle East and Islamic World Reader. New York: Grove Press.

Gulfnews (2007). Iran and Saudi leaders in key talks Retrieved 12 October, 2008, from http://gulfnews.com/news/region/iran/iran-and-saudi-leaders-in-key-talks-1.165268

Hiro, D. (2001). Neighbors, Not Friends: Iraq and Iran After the Gulf Wars. London: Routledge.

Hufbauer, G. C., Schott, J. J., \& Elliott, K. A. (1991). Economic Sanctions Reconsidered: History and Current Policy. Washington DC: Peterson Institute.

Husseini, H. (2007). Reviewing Iran-Saudi relations Retrieved 12 August, 2008, from http://www.bashgah.net/modules.php?name=Articles\&op=show\&aid=15264.

Institution for Political Research and Studies (2007). Reviewing History of Iran-Saudi Relations Retrieved 20 September, April 2008, from http://www.irdc.ir/article.asp?id=973

Ismael, T. Y., \& Ismael, J. S. (1994). The Gulf War and the New World Order. Gainesville: University Press of Florida.

Kaim, M. (2008). Great Powers and Regional Orders: The United States and the Persian Gulf. London: Ashgate Publishing.

Kamrava, M. (2005). The Modern Middle East: A Political History Since the First World War. Berkeley: University of California Press.

Levran, A. (1997). Israeli Strategy After Desert Storm: Lessons of the Second Gulf War. London: Routledge.

Mansbach, R. W. \& Rafferty, K. L. (2008). Introduction to Global Politics. London: Routledge.

Marschall, C. (2003). Iran's Persian Gulf Policy: From Khomeini to Khatami. London: Routledge. 
Metz, H. C. (2004). Saudi Arabia A Country Study. Montana: Kessinger Publishing.

Mohaddessin, M. (2003). Islamic Fundamentalism. New Delhi: Anmol Publications PVT. LTD.

Nonneman, G. (2005). Analyzing Middle East Foreign Policies and the Relationship with Europe: And the Relationship with Europe. London: Routledge.

Parsi, T. (2007). Treacherous Alliance: The Secret Dealings of Israel, Iran, and the United States. New Haven: Yale University Press

Robert, P. (2005). The End of Oil: On the Edge of a Perilous New World. New York: Mariner Books.

Schaeffer, R. K. (2005). Understanding Globalization: The Social Consequences of Political, Economic, and Environmental Change. Lanham: Rowman\& Littlefield.

Scheffer, D. J. (1991). Use of Force after the Cold War: Panama, Iraq, and The New World Order. In L. H. Henkin, Stanley; Kirkpatrick, Jeane J.; Swing, John T. (Ed.), Right v. Might: International Law and the Use of Force (pp. 108-172). New York: Council on Foreign Relations Press.

Thies, C. G. (2006). From containment to the Bush doctrine: the road to war with Iraq. In J. Davis (Ed.), Presidential Policies and the Road to the Second Iraq War (pp. 193-207). London: Ashgate Publishing.

Walt, S. M. (1996). Revolution and War. New York: Cornell University Press.

Wilson, P. W. \& Graham, D. F. (1994). Saudi Arabia: The Coming Storm. New York: Sharpe, M.e.

Yaqubi, S. (2009). The Foreign Policy of Iran During Constructiveness Period. Tehran: The Center For Islamic Revolution Of Iran. 